\title{
Growth Hormone Responses to Arginine Infusion in Patients with Chronic Pancreatitis : Relationship to Glucose Intolerance and Insulinopenia
}

\author{
W.J. Kalk, B.L. Pimstone, and W.P.U. Jackson \\ Department of Medicine, University of Cape Town, South Africa \\ Received: January 28, 1974, and in revised form June 24, 1974
}

\begin{abstract}
Summary. The growth hormone (HGH) and insulin. responses to intravenous arginine infusion were studied in 21 patients (13 males and 8 females) with chronic pancreatitis. Ten of these patients had glucose intolerance, 5 with fasting hyperglycaemia, while 11 patients had subnormal insulin responses to arginine. Basal HGH
\end{abstract}

levels and peak responses to arginine were normal but were uninfluenced by sex, glucose intolerance, fasting hyperglycaemia or insulinopenia.

Key words: Human growth hormone, pancreatitis, insulinopenia, diabetes, arginine.
Patients with genetic diabetes mellitus may have increased spontaneous human growth hormone (HGH) secretion $[1,2]$. Abnormalities of plasma HGH responses to various provocative stimuli have also been demonstrated and have been reported as subnormal, paradoxical or exaggerated $[3,4,5,6,7,8,9,10]$. The present study presents data on the HGH responses to intravenous arginine infusion in patients with chronic pancreatitis. Since many of these patients are diabetic $[11]$, and may be insulinopenic $[12,13]$, the effects of glucose intolerance, chronic hyperglycaemia and insulinopenia could be studied independently of the genetic effects of spontaneous diabetes mellitus. Our results indicate that most patients with chronic pancreatitis have substantial HGH responses to arginine, uninfluenced by sex or by the presence or absence of glucose intolerance or insulinopenia.

\section{Material and Methods}

Twenty-one patients, 13 males and 8 females, aged from 21 to 64 years were studied. All had suffered typical episodes of acute pancreatitis with elevated serum and/or urinary amylase levels [11]. The presence of chronic pancreatitis was confirmed by radiologically evident pancreatic calcification, by the development of pancreatic pseudocysts, or by laparotomy. All patients underwent standard tests of pancreatic exocrine function, which were shown to be abnormal in all but 3 patients [14] (Table 1).

Only 1 patient had a family history of diabetes mellitus. No patient was on insulin or oral antidiabetic therapy or was taking drugs known to effect HGH secretion at the time of testing.

A $50 \mathrm{~g}$ oral glucose tolerance test was performed on all patients as a screening procedure. Blood was taken before and at $30 \mathrm{~min}$ intervals after the glucose load for 2 hrs.
Intravenous arginine infusions were performed at rest after an overnight fast. A polythene cannula was inserted into an antecubital vein, after which 3 basal blood samples were taken. $30 \mathrm{~g}$ of buffered arginine monohydrochloride in $100 \mathrm{ml}$ of $0.9 \%$ saline was then infused over $30 \mathrm{~min}$. Further blood samples were taken $10,20,30,40,50,60,75$ and 90 min after the commencement of the infusion. Blood glucose was estimated immediately by the ferricyanide, reduction method of Hoffman [15], using an auto-analyser. Aliquots of plasma were deep frozen until assayed for immunoreactive insulin (IRI) by the method of Hales and Randle [16] and for HGH by the method of Morgan and Lazarow [17], using HGH obtained from the National Pituitary Agency, U.S.A. (HS 1394) for iodination and as reference standard. HGH assay sensitivity was $1 \mathrm{ng} / \mathrm{ml}$.

The incremental insulin values above mean basal levels for the 0-60 min period were plotted and the total area under this insulin incremental curve was calculated using an Olivetti P203 desk computer. These data were compared to values obtained in 7 normal male subjects tested in an identical manner. Results were analysed statistically using the MannWhitney-U test.

\section{Results}

Glucose Tolerance, Insulin and Growth Hormone Responses to Arginine

Ten patients were considered to have 'diabetic' glucose tolerance tests according to the criteria of Jackson and Vinik [18]; 5 of these had fasting hyper. glycaemia (fasting blood glucose above $120 \mathrm{mg} / 100 \mathrm{ml}$ ). The remaining 11 subjects had normal oral glucose tolerance.

The basal HGH concentration was regarded as the lowest fasting HGH level in each patient before the 
Table 1. Oral glucose tolerance (OGTT), mean fasting blood glucose and plasma immunoreactive insulin (IRI), area of $I R I$ increment after IV arginine, basal and peak post arginine plasma human growth hormone (HGH) in 21 patients with chronic pancreatitis. OGTT is classified as either normal $(N)$ or diabetic $(D)$ as explained in text. The fasting glucose and IRI values are a mean of 3 samples taken in the basal state (see text). The asterisk* marks the IRI responses to arginine below the range of the controls i.e. $<300 \mu \mathrm{U} \cdot \mathrm{ml}^{-1} \cdot 60 \mathrm{~min}$ (Mean of 7 controls $1424.7^{4} \pm 533.4 \mu U \cdot \mathrm{ml} \mathrm{l}^{-1} \cdot 60 \mathrm{~min}$ ). Pancreatic function tests (PFT) are included for all but 2 patients who had a history of recurrent acute pancreatitis and pancreatic calcification radiologically (see text). Normal values for PFT are volume $>140 \mathrm{ml}, \mathrm{HCO}>80 \mathrm{mH} / \mathrm{L} ; \mathrm{Amylase}>5 \mathrm{U} / \mathrm{ml}$ and Lipase $>300 \mathrm{U} / \mathrm{ml}$

\begin{tabular}{|c|c|c|c|c|c|c|c|c|c|c|c|}
\hline \multirow[t]{2}{*}{ Patient } & \multirow[t]{2}{*}{ Sex } & \multirow[t]{2}{*}{ OGTT } & \multirow{2}{*}{$\begin{array}{l}\text { Mean } \\
\text { fasting } \\
\text { glucose } \\
\text { mg/100 } \mathrm{ml} \\
\end{array}$} & \multirow{2}{*}{$\begin{array}{l}\text { Mean } \\
\text { fasting } \\
\text { IRI } \\
\mu \mathrm{U} / \mathrm{ml}\end{array}$} & \multirow{2}{*}{$\begin{array}{l}\text { IRI incre- } \\
\text { ment after } \\
\text { IV arginine } \\
\mu \mathrm{U} \cdot \mathrm{ml}^{-\mathbf{1}} \cdot 60 \mathrm{~min}\end{array}$} & \multirow{2}{*}{$\begin{array}{l}\text { Basal } \\
\mathrm{HGH} \\
\mathrm{ng} / \mathrm{ml}\end{array}$} & \multirow{2}{*}{$\begin{array}{l}\text { Peak } \\
\text { HGH } \\
n g / m l\end{array}$} & \multicolumn{4}{|c|}{$\begin{array}{l}\text { Pancreatic response to CCK-PZ } \\
\text { secretin }\end{array}$} \\
\hline & & & & & & & & $\begin{array}{l}\text { Volume } \\
\text { ml }\end{array}$ & $\begin{array}{l}\mathrm{HCO}_{3} \\
\mathrm{mEq} / 1\end{array}$ & $\begin{array}{l}\text { Amylase } \\
\mathrm{U} / \mathrm{ml}\end{array}$ & $\begin{array}{l}\text { Lipase } \\
\mathrm{U} / \mathrm{ml}\end{array}$ \\
\hline $\mathrm{TD}$ & M & $\mathrm{N}$ & 82 & 18.0 & $262 *$ & 3.3 & 23.5 & 112 & 34 & 10.6 & 1120 \\
\hline JE & $\mathbf{M}$ & $\mathrm{N}$ & 93 & 17.7 & $252 *$ & 0.8 & 6.2 & 191 & 45 & 5.4 & - \\
\hline $\mathrm{TB}$ & $\bar{M}$ & $\mathrm{~N}$ & 100 & 20.3 & $47 *$ & 13.7 & 25.0 & 38 & 48 & 2.8 & 354 \\
\hline $\mathrm{BT}$ & $\mathbf{M}$ & $\mathbf{N}$ & 98 & 24.7 & 1979 & 0.5 & 4.9 & 164 & 46 & 3.2 & 229 \\
\hline JP & $\mathbf{M}$ & $\mathrm{N}$ & 96 & 8.0 & $280 *$ & 6.2 & 50.0 & 121 & 65 & 4.3 & 318 \\
\hline JB & $\mathbf{M}$ & $\mathbf{N}$ & 95 & 20.3 & 1015 & 0.5 & 3.9 & - & - & - & - \\
\hline $\mathrm{JE}$ & M & $\mathrm{N}$ & 100 & 20.3 & $0 *$ & 2.5 & 66.1 & 182 & 51 & 3.2 & 495 \\
\hline MW & F & $\mathrm{N}$ & 94 & 16.3 & 3110 & 1.7 & 10.5 & 241 & 83 & 11.9 & 729 \\
\hline MP & $\mathbf{F}$ & $\mathrm{N}$ & 74 & 8.0 & 887 & 0.4 & 26.1 & 211 & 68 & 6.5 & 323 \\
\hline $\mathrm{MP}$ & $\mathrm{F}$ & $\mathbf{N}$ & 88 & 10.0 & 307 & 6.8 & 36.0 & 103 & 38 & 6.1 & 881 \\
\hline $\mathrm{JS}$ & $\mathrm{F}$ & $\mathbf{N}$ & 85 & 10.7 & $32 *$ & 6.4 & 8.3 & 129 & 88 & 10.5 & 1177 \\
\hline $\mathrm{PP}$ & $\mathbf{M}$ & $\mathrm{D}$ & 355 & 16.7 & $0^{*}$ & 1.7 & 24.0 & 66 & 31 & 2.8 & 198 \\
\hline MI & $\mathbf{M}$ & D & 116 & 15.7 & 564 & 2.6 & 29.0 & 120 & 32 & 1.3 & 63 \\
\hline JM & $\mathrm{M}$ & $\mathrm{D}$ & 72 & 22.3 & 506 & 2.1 & 19.8 & 247 & 38 & 3.4 & 297 \\
\hline WH & $\mathrm{M}$ & $\mathrm{D}$ & 139 & 24.0 & $147^{*}$ & 1.8 & 28.5 & 145 & 59 & 4.9 & 375 \\
\hline $\mathrm{JM}$ & $\mathrm{M}$ & $D$ & 124 & 18.0 & 310 & 0.6 & 9.2 & 138 & 50 & 1.5 & 209 \\
\hline WR & $\mathrm{M}$ & $D$ & 87 & 17.7 & $198 *$ & 1.4 & 50.0 & 159 & 35 & 2.4 & 459 \\
\hline MP & $\mathrm{F}$ & $\mathrm{D}$ & 83 & 12.7 & 380 & 1.3 & 20.9 & - & 26 & 10.5 & - \\
\hline LM & $\mathrm{F}$ & $\bar{D}$ & 259 & 28.0 & $0 *$ & 2.4 & 6.8 & 219 & 50 & 3.4 & - \\
\hline LH & $\mathrm{F}$ & $\mathrm{D}$ & 159 & 11.0 & $245^{*}$ & 2.9 & 27.0 & - & - & - & - \\
\hline GduP & $F$ & $\mathrm{D}$ & 98 & 18.3 & 942 & 1.3 & 25.5 & 66 & 24 & 12.1 & - \\
\hline
\end{tabular}

Table 2. Fasting blood glucose, plasma IRI, basal and peak plasma HGH concentrations in pancreatitis patients with normal and diabetic glucose tolerance

\begin{tabular}{|c|c|c|c|}
\hline & Normal GTT $(n=11)$ & Diabetic GTT $(n=10)$ & $\overline{\text { Significance }}$ \\
\hline $\begin{array}{l}\text { Mean fasting glucose ( } \pm \text { SEM) } \\
\mathrm{mg} / 100 \mathrm{ml}\end{array}$ & $91.4 \pm 2.5$ & $148.7 \pm 28.5$ & $p<0.05$ \\
\hline $\begin{array}{l}\text { Mean fasting IRI ( } \pm \text { SEM) } \\
\mu \mathrm{U} / \mathrm{ml}\end{array}$ & $15.9 \pm 1.7$ & $18.4 \pm 1.6$ & NS \\
\hline $\begin{array}{l}\text { Mean basal HGH }( \pm \text { SEM) } \\
\text { ng/ml } \\
\text { Range }\end{array}$ & $\begin{array}{l}3.9 \pm 1.3 \\
(0.4 \pm 13.7)\end{array}$ & $\begin{array}{l}1.8 \pm 0.2 \\
(0.6-2.9)\end{array}$ & NS \\
\hline $\begin{array}{l}\text { Mean peak HGH ( } \mathrm{H} \text { SEM) } \\
\text { ng/ml } \\
\text { Range }\end{array}$ & $\begin{array}{l}23.4 \pm 6.1 \\
(3.9 \pm 66.1)\end{array}$ & $\begin{array}{l}25.1 \pm 3.9 \\
(6.8-35.5)\end{array}$ & NS \\
\hline
\end{tabular}

Table 3. Fasting blood glucose, plasma IRI, basal and peak plasma $H G H$ concentrations in pancreatitis patients with normal and insulinopenic responses to IV arginine

\begin{tabular}{|c|c|c|c|}
\hline & $\begin{array}{l}\text { Normal IRI responders } \\
(\mathrm{n}=10)\end{array}$ & $\begin{array}{l}\text { Insulinopenic patients } \\
(\mathrm{n}=11)\end{array}$ & Significance \\
\hline $\begin{array}{l}\text { Range of insulin area after arginine } \\
\left(\mu \mathrm{U} \cdot \mathrm{ml}^{-1} \cdot 60 \mathrm{~min}\right)\end{array}$ & $307-3110$ & $0-280$ & \\
\hline $\begin{array}{l}\text { Mean fasting glucose ( } \pm \text { SEM }) \\
\text { mg/100 ml }\end{array}$ & $94.2 \pm 5.2$ & $141.1 \pm 26.5$ & $p<0.05$ \\
\hline Mean fasting IRI $( \pm \mathrm{SEM}) \mu \mathrm{U} / \mathrm{ml}$ & $16.6 \pm 1.7$ & $17.5 \pm 1.8$ & N.S. \\
\hline $\begin{array}{l}\text { Mean basal HGH ( } \mathrm{H} \text { SEM) } \mathrm{ng} / \mathrm{ml} \\
\text { Range }\end{array}$ & $\begin{array}{c}1.8 \pm 0.6 \\
(0.4-6.8)\end{array}$ & $\begin{array}{l}3.9 \pm 1.1 \\
(1.4 \pm 13.7)\end{array}$ & $p<0.05$ \\
\hline $\begin{array}{l}\text { Mean peak HGH ( } \mathrm{HSEM} \text { ) ng/ml } \\
\text { Range }\end{array}$ & $\begin{array}{r}18.6 \pm 3.5 \\
(3.9-50)\end{array}$ & $\begin{array}{l}28.7 \pm 5.9 \\
(6.8-66.1)\end{array}$ & N.S. \\
\hline
\end{tabular}


start of infusion, while the highest HGH level attained during or after the infusion was considered to be the peak concentration. Mean ( \pm SEM) basal HGH value for all patients was $2.9 \pm 0.7 \mathrm{ng} / \mathrm{ml}$. In 19 of the 21 patients a peak level above $6 \mathrm{ng} / \mathrm{ml}$ was elicited between 20 and 75 min after the start of the infusion. The mean peak value was $24.3 \pm 3.6 \mathrm{ng} / \mathrm{ml}$. (Table 1 )

Ten patients had serum insulin responses to arginine within the range of the controls (control range 305 to $3875 \mu \mathrm{U} \cdot \mathrm{ml}^{-1} \cdot 60 \mathrm{~min}$ ) i.e. they were "normal" responders. A further 11 had either reduced IRI response (below $300 \mu \mathrm{U} \cdot \mathrm{ml}^{-1} \cdot 60 \mathrm{~min}$ ) or no rise at all - designated the 'insulinopenic' patients (Table 1).

\section{The Influence of Sex on $H G H$ Responses}

Mean basal HGH values were the same in males $(2.9 \pm 1.0 \mathrm{ng} / \mathrm{ml})$ and females $(2.9 \pm 0.9 \mathrm{ng} / \mathrm{ml})$ and the mean peak concentrations were insignificantly different $(26.2 \pm 5.3 \mathrm{ng} / \mathrm{ml}$ - males, $21.4 \pm 4.2 \mathrm{ng} / \mathrm{ml}-$ females). Only 2 male subjects failed to achieve $\mathrm{HGH}$ peak above $6 \mathrm{ng} / \mathrm{ml}$.

\section{The Influence of Glucose Intolerance on HGH Responses}

Mean basal and peak HGH levels of the 10 patients with normal glucose tolerance did not differ significantly from those of the 11 diabetic subjects (Table 2).

\section{The Influence of Fasting Blood Glucose Concentration on $H G H$ Response}

Five patients had fasting hyperglycaemia (206.6 $\pm 44 \mathrm{mg} / 100 \mathrm{ml}$ ). The remaining 16 patients had fasting glucose levels below $120 \mathrm{mg} / 100 \mathrm{ml}$. The mean basal HGH concentrations in the hyperglycaemic and normoglycaemic groups were similar $(2.0 \pm 0.3$ and $3.3 \pm 0.9 \mathrm{ng} / \mathrm{ml}$ respectively), as were the peak $\mathrm{HGH}$ levels $(20.8 \pm 4.1 \mathrm{ng} / \mathrm{ml}$ and $25.8 \pm 4.8 \mathrm{ng} / \mathrm{ml}$ respectively).

\section{The Influence of Insulin Responses to Arginine on Growth Hormone Responses}

The patients were subdivided according to their insulin responses to the infused arginine. Ten were found to have insulin increments within the range of the controls (above $300 \mu \mathrm{U} \cdot \mathrm{ml}^{-1} \cdot 60 \mathrm{~min}$ ); $11 \mathrm{had}$ subnormal responses - the "insulinopenie" patients (see above). Mean basal HGH concentration was slightly greater in the "insulinopenic" group compared to "normal" (Table 3), whereas the peak HGH concentrations were not significantly different.

Only 5 "insulinopenic" subjects had glucose intolerance while 5 patients with "normal" IRI values were diabetic.

\section{Discussion}

Basal plasma HGH levels and responses to I.V. arginine in our patients with pancreatitis were within the normal range reported by others. This contrasts with a previously reported finding of rather poor HGH responses to insulin hypoglycaemia in 6 pancreatitic patients compared to matched controls [19]. However, in that study peak HGH concentrations were within the accepted range of normal in 5 of the patients [20].

When the patients were separated according to sex, the expected differences $[8,21]$ in basal and peak HGH concentrations were not found. The unexpectedly frequent high HGH responses in the males may be related to the fact that they were all chronic alcoholics and might have had relative oestrogen excess [22]. However, other authors have found high. $\mathrm{HGH}$ responses to $\mathrm{I}$. $\mathrm{V}$. arginine in most male subjects [8].

As both fasting HGH levels and the peak responses to arginine were similar in patients with diabetic and normal glucose tolerance, glucose intolerance per se does not appear to influence the HGH responses in pancreatitis subjects confirming the reports that hyperglycaemia does not blunt HGH responses to arginine [23]. A similar finding in genetic diabetics has been reported [8], although there are contrary views $[10,24]$.

The slightly higher basal HGH levels in the insulinopenic patients may reflect increased spontaneous HGH secretion as reported in genetic diabetes $[1,2]$, but the levels are within the normal range. The good $\mathrm{HGH}$ responses in our insulinopenic group contrast with poor insulin and HGH responses found in maturity onset diabetics by Merimee et al. [24], but are similar to the reported normal HGH responses to arginine in juvenile, insulinopenic diabetics [25].

\section{Conclusion}

It appears that most patients with chronic pancreatitis have normal basal and post arginine plasma HGH levels. These responses appear to be indifferent to the effects of glucose intolerance, fasting hyperglycaemia or subnormal insulin responses to arginine. No sex differences were found.

Acknowledgments. This study was supported by the South African Medical Research Council, South African Atomic Energy Board and University of Cape Town Staff Research Fund.

\section{References}

1. Molnar, G.D., Ackerman, E., Rosevear, J.W., Gatewood, L. C., Moxness, K. E.: Continuous blood glucose analysis in ambulatory fed subjects. I General Methodology. Mayo Clin. Proc. 43, 833-851 (1968)

2. Johansen, K., Hansen, Aa.P.: Diurnal serum growth hormone levels in poorly and well-controlled juvenile diabetics. Diabetes 20, 239-245 (1971)

3. Sabeh, G., Corredar, D. G., Mendelsohn, L. V., Morgan, C.R., Sierahi, J.C., Sunder, J.H., Wingert, J.P., 
Danowski, T.S.: Growth hormone levels in newly discovered glucose intolerance. Metabolism 18, 741$747(1969)$

4. Sabeh, G., Mendelsohn, L.V., Corredor, D.G., Sunder, J.H., Morgan, C.R., Danowski, T.S.: Growth hormone in insulin treated diabetes mellitus. Metabolism 18, 748-753 (1969)

5. Yde, H.: Abnormal growth hormone response to ingestion of glucose in juvenile diabetes. Acta med. scand. 186, $499-504$ (1969)

6. Fatourechi, V., Molnar, C.D., Service, F.J., Ackerman, E., Rosevear, J.W., Moxness, K.E., Taylor, W.F.: Growth hormone interrelationships in diabetes: Studies with insulin infusion during continuous blood glucose analysis. J. clin. Endocr. 29, 319-327 (1969)

7. Hansen, A.P.: Abnormal serum growth hormone response to exercise in juvenile diabeties. J. clin. Invest. 49, 1467-1478 (1970)

8. Tchobroutsky, G., Rosselin, G., Assan, R., Derot, M.: Arginine infusion in diabetes mellitus. Lancet 1966 II, 498

9. Merimee, T.J., Rabinowitz, D., Riggs, L., Burgess, J.A., Rimoin, D.L., McKusick, V.A.: Plasma growth hormone after arginine infusion. New Engl. J. Med. 276, 434-439 (1967)

10. Burday, S.Z., Fine, P.F., Schalch, D.S.: Growth hormone secretion in response to arginine infusion in normal and diabetic subjects : Relationship to glucose levels. J. Lab. clin. Med. 71, 897-911 (1970)

11. Marks, I.N., Bank, S., Louw, J.H.: The diagnosis and management of pancreatitis. Progress in Gastroenterology. Grune and Stratton, 412-472 (1968)

12. Bank, S., Jackson, W.P.U., Keller, P., Marks, I.N.: Serum-insulin response to glucose in "pancreatic diabetes". Postgrad. med. J. 44, 214-217 (1968)

13. Joffe, B.I., Bank, S., Jackson, W.P.U., Keller, P. O'Reilly, I.G., Vinik, A.I.: Insulin reserve in patients with chronic pancreatitis. Lancet 1968 II, 890

14. Bank, S., Marks, I.N., Moshal, M.G., Efron, G., Silber, R.: The pancreatic function test - method and normal values. S. Afr. med. J. 37, 1061-1066 (1963)

15. Hoffman, W.S. : A rapid photoelectric method for the determination of glucose in blood and urine. J. biol. Chem. 120, 51 (1937)
16. Hales, C.N., Randle, P.J.: Immunoassay of insulin with insulin-antibody precipitate. Biochem. J. 88, $137-146$ (1963)

17. Morgan, C.R., Lazarow, A. : Immunoassay of insulin: two antibody system. Diabetes 12, 115-126 (1963)

18. Jackson, W.P.U., Vinik, A.I.: Does hyperglycaemia mean Diabetes? Med. Proc. 16, 362-365 (1970)

19. Vinik, A.I., Joffe, B.I., Joubert, S.M., Jackson, W.P.U.: Growth hormone response to insulin-induced hypoglycaemia in diabetes secondary to chronic calcific pancreatitis. J. clin. Endocr. 31, 86-88 (1970)

20. Youlton, R., Kaplan, S.L., Grumbach, M.M.: Growth and growth hormone IV: Limitations of the growth hormone response to insulin and arginine and of the insulin response to arginine in the assessment of growth hormone deficiency in children. Paediatrics 43, 989-1004 (1969)

21. Merimee, T.J., Burgess, J.A., Rabinowitz, D.: Sex determined variation in serum insulin and growth hormone response to amino acid stimulation. J. clin. Endocr. 26, $791-793$ (1966)

22. Chopra, J., Tulchinsky, D., Greenway, F. L.: Oestrogen-androgen imbalance in hepatic cirrhosis. Ann. intern. Med. 79, 198-203 (1973)

23. Rabinowitz, D., Merimee, T.J., Burgess, J.A., Riggs, L.: Growth hormone and insulin release after arginine: indifference to hyperglycaemia and epinephrine. J. clin. Endocr. 26, $1170-1172(1966)$

24. Merimee, T.J., Burgess, J.A., Rabinowitz, D.: Arginine infusion in maturity onset diabetes mellitus. Lancet 1966 I, 1300

25. Parker, M.L., Pilder, R.S., Choa K-.L., Cornblath, M., Kipnis, D.M.: Juvenile diabetes mellitus, a deficiency of insulin. Diabetes 17, 27-32 (1968)

B. L. Pimstone, M.D.

Assoc. Prof. of Medicine

Univ, of Cape Town

Dept. of Medicine

Medical School Observatory

Cape Town

South Africa 